\title{
Let Your Faith Be Bigger Than Your Fear
}

\author{
Pallavi Damale ${ }^{1}$ \\ ${ }^{1}$ Legal Cloudmoyo India Pvt Ltd, Baner, Pune, Maharashtra, India \\ Ind J Med Paediatr Oncol 2021;42:466-467.
}

In June 2019, at the age of 30, I was diagnosed with stage II bilateral breast cancer. Till that point I was, as others would say, was in the pink of my health. I was leading a normal life without ever suffering from any major illnesses.

Post the birth of my child, I started regular self-breast examinations. It was then, when I noticed a small painful lump on the upper side of my left breast. Without any delay, we rushed to our family doctor. However, after the physical examination, our family doctor said, "There was nothing to worry about! The lump is actually a milk gland which will eventually subside." I further read about cancerous lumps and cysts and I found out that they are usually not painful and, in my case, there was pain without any other symptoms, hence I relaxed.

Over the next month, nothing unusual occurred and I followed my routine. However, the pain did not reduce. I also observed that the pain increased before and during my menstrual cycle. I consulted a doctor and was advised to do fine-needle aspiration cytology and breast sonography, but the test results were negative. I was relieved yet again at that point. However, I was unaware that this relaxed state was only temporary!

Within the next 2 months, the lump grew drastically (almost doubled in size) because of which the breasts became extremely tender and painful. The doctors suggested lumpectomy-removal of the lump. And accordingly, I underwent the surgery. Post procedure, my worries had reduced as I believed that the cause of my illness was removed, I was looking forward to resuming my routine at home. However, to my dismay that did not happen. My reports postsurgery came positive and I was diagnosed with invasive ductal carcinoma-stage II. This news was devastating and even more so as we were not expecting it at the least.

The next morning, I underwent a second set of positron emission tomography computed tomography (PET CT) scans. The news, however, was worse this time. Four small lumps
Address for correspondence Pallavi Damale, Legal Cloudmoyo India Pvt Ltd, Baner, Pune, Maharashtra, India (e-mail: dpallavi1989@gmail.com).

were found on the lower side of the right breast. Fortunately, the cancer had not spread anywhere else in the body throughout the treatment, which was the silver lining.

I wasn't aware of the ABCDs of breast cancer at the time. One of my closest family members was also fighting cancer. This made me want to research more on the disease, during which I read a lot of disturbing facts and statistics which affected me psychologically and many questions arose in my head. Questions like: "Was I going to die? Why Me? What about my daughter? Can I lead my normal life after the treatment?" came into my mind. It took time for me to accept the reality and however once I did, I started reading even more on cancer. It included books like "Anti-cancer-A New Way of Life"1 and "Anti-cancer Living." ${ }^{2}$ These books elevated my mood and allowed me to become more hopeful and get into a positive mindset. Additionally, meditation helped me a lot to maintain the positive attitude throughout my treatment. As one of my relatives was getting treated at a tertiary care centre in Pune, I decided to seek a second opinion. The doctors there boosted my confidence and assured me that I would be able to lead a normal life after finishing the treatment. As per my oncologist's advice, I got myself tested for the Cancer Genetic Test at the same hospital. My genetic test result was positive, as anticipated.

The doctors performed core biopsy during the period. After seeking opinions of multiple oncologists, I chose to complete my treatment at the same hospital. The doctors were very motivating however, self-belief, my faith, my daughter's love and the company of my dear ones also gave me the strength and confidence to believe that I would overcome it. Along with my positive attitude, my family's strong and firm support helped me a lot to fight this undesired journey. My daughter was my biggest strength as she stood by me like a rock each and every moment of the treatment. Being with her joyful self, helped me forget about situation and focus on living life.
DOI https://doi.org/ 10.1055/s-0041-1740603. ISSN 0971-5851.
(C) 2021. Indian Society of Medical and Paediatric Oncology. All rights reserved.

This is an open access article published by Thieme under the terms of the Creative Commons Attribution-NonDerivative-NonCommercial-License, permitting copying and reproduction so long as the original work is given appropriate credit. Contents may not be used for commercial purposes, or adapted, remixed, transformed or built upon. (https://creativecommons.org/ licenses/by-nc-nd/4.0/)

Thieme Medical and Scientific Publishers Pvt. Ltd., A-12, 2nd Floor, Sector 2, Noida-201301 UP, India 
We had many discussions with my doctors about treatment options and latest medications. The doctors patiently answered all our queries. The support given by the doctors was commendable and we are grateful for that. It is very important to trust your doctors during the treatment as this helps to boost the confidence and in turn mental health. Cancer takes away many things from you, but what I have experienced is that it gives much more in return which I now fully realize.

Opting for bilateral mastectomy (removal of both the breasts) was the hardest decision of my life as I was only 30 years of age. We decided to opt for neoadjuvant chemotherapy first which allowed us a little extra time-to make a decision about the procedure. Over a period of time, I started noticing the side effects of chemotherapy. I experienced hair fall and blackening of fingernails. However, this was not all! It was extremely difficult to see my hair come off in bunches every now and then. So, I decided to end this pain once and for all by shaving my head. As a woman, I think, this was the hardest thing I had to do. Eventually however, I accepted it. Then, chemotherapy became the "new normal" for me. But I was assured that it was only temporary. With many ups and downs, I completed two cycles of chemotherapy (4 chemotherapies in 1 cycle).

Comparing my situation to others, I was certain that I had not got the worst of the lot, there were other patients with even more complications than I had. I realized the power of "Positivity in Negativity." During my chemotherapy-I hardly went out as I was scared of catching any kind of infection. The exception to the rule were the visits to the hospital. However, after the second chemo, my fears materialized and I caught a viral fever for which I had to be hospitalized for 8 days. This experience was quite a learning curve.

Post-chemotherapy, the doctors recommended a set of PET CT scans and, this time, my PET CT report came back negative.
Surgery was the next step post-chemotherapy. Reviewing my reports, the doctor recommended mastectomy. Lumpectomy was not that drastic an option, however mastectomy was! After discussions with family members and doctors, I realized that the stage and state of cancer meant recurrence and to avoid it, mastectomy was the best solution.

Accordingly, I underwent bilateral modified radical mastectomy in December 2019. The first 2 weeks post-surgery were very crucial as there was limited movement of shoulders and arms. Assessing my condition, the doctors recommended physiotherapy and it worked wonders!

Today, I am leading a normal life. I am completely satisfied with what I have today. I wanted to contribute to helping people who faced similar issues. Hence, I joined groups like Care Cancer Peer Support Group and Ubhari. I wanted to create awareness among people, especially women. I was invited to share my experience regarding this journey at Deccan Gymkhana Club and MIT School of Education.

In a true sense, cancer has taught me so many things. My family and friends are the pillars of strength in tough times. Without all of them, this journey would have not been possible. I feel proud and lucky to have them in my life. Through all this, I have realized that it is important to take everything as it comes because we don't always know what's in the store. So, Carpe Diem!

Conflict of Interest

None declared.

\section{References}

1 Servan-Schreiber D. Anticancer: A New Way of Life. Penguin UK 2011

2 Cohen L, Jefferies A. Anticancer Living: Transform Your Life and Health with the Mix of Six. Vermillion 2018 